American University Washington College of Law

Digital Commons @ American University Washington College of

Law

Articles in Law Reviews \& Other Academic Journals

Scholarship \& Research

2007

\title{
An Empirical Analysis of Investment Treaty Awards
}

Susan Franck

American University Washington College of Law, sfranck@wcl.american.edu

Follow this and additional works at: https://digitalcommons.wcl.american.edu/facsch_lawrev

Part of the Banking and Finance Law Commons, and the Dispute Resolution and Arbitration Commons

\section{Recommended Citation}

Franck, Susan, "An Empirical Analysis of Investment Treaty Awards" (2007). Articles in Law Reviews \& Other Academic Journals. 1594.

https://digitalcommons.wcl.american.edu/facsch_lawrev/1594

This Article is brought to you for free and open access by the Scholarship \& Research at Digital Commons @ American University Washington College of Law. It has been accepted for inclusion in Articles in Law Reviews \& Other Academic Journals by an authorized administrator of Digital Commons @ American University Washington College of Law. For more information, please contact kclay@wcl.american.edu. 


\title{
An Empirical Analysis of Investment Treaty Awards
}

\author{
By Susan D. Franck*
}

\section{INTRODUCTION}

Earlier speakers offered insights about investment law and its implications for the future of domestic administrative law and international law. To bring us full circle, I will discuss where we are today so that we can consider where we want development law to be tomorrow. In pursuit of that goal, I offer empirical data related to investment treaty arbitration. ${ }^{1} \mathrm{My}$ goal today is to focus on three claims about investment treaty arbitration and consider the data's potential implications.

\section{InVestment Treaties AND Empirical Legal Research}

By the end of 2005, there were at least 2,495 investment treaties signed by over 175 different countries. Of these signed treaties, approximately $75 \%$ were in force. ${ }^{2}$ Investment treaties articulate substantive investment rights, such as freedom from discrimination and assurances of fair and equitable treatment. They also provide procedural rights granting investors direct access to dispute resolution with host governments. Given that we now know that investors utilize these rights, the question is: what reliable information do we have about the resolution of investment treaty conflict?

At present, there is little empirical research that considers investment treaty conflict on a systematic basis. This may be due to the novelty of the area as well as the difficulty of gathering data. While not a cure for all ills, empirical analysis can create a vital nexus between the practical reality and theory that has the potential to promote long-term integrity and legitimacy of international law. In the short term, it also promotes informed debate and decision-making of parties, lawyers, arbitrators and the public.

\section{The Research Project and Results}

Mindful of the need to start somewhere, my research gathered data about investment treaty conflict by analyzing publicly available arbitration awards. The methodology involved selecting, gathering, and coding data from the population of all investment treaty awards that were publicly available before June $1,2006 .{ }^{3}$ It is vital to keep this in mind as it necessarily excluded cases that did not result in an arbitration award and/or awards that were not publicly available. ${ }^{4}$

Overall, the population contained 82 cases (i.e., treaty disputes spawning at least one award). These 82 cases spawned a total of 102 awards arising out of 49 different investment treaties. There were 52 awards finally resolving investment treaty disputes. But what can

\footnotetext{
* Assistant Professor of Law, University of Nebraska Law College. The author encourages readers to rely upon the published version in the North Carolina article, as these remarks reflect the state of research at the time of the ASIL Annual Meeting.

${ }^{1}$ North Carolina Law Review (forthcoming), available in draft form at <http://papers.ssrn.com/sol3/ papers.cfm?abstract_id=969257>.

${ }^{2}$ United Nations Commission on Trade and Development, The Entry into Force of Bilateral Investment Treaties (BITs), IIA Monitor No. 3 (2006), at <http://www.unctad.org/en/docs/webiteiia20069_en.pdf>.

${ }^{3}$ See North Carolina Law Review article for a description of the methodology.

${ }^{4}$ It also excludes preliminary decisions and/or post-award activity by national courts and/or ad hoc committees.
} 
this population tell us about the investment treaty arbitration and the validity of claims about the process?

\section{Investors Win More Often than Governments?}

The literature suggests there is confusion about who wins and loses investment treaty arbitration. Some suggest investors are primarily successful and implicate governments are unfairly disadvantaged. Others suggest the process is not completely one-sided. ${ }^{5}$ But what did the data say?

Out of the 52 awards finally resolving treaty claims, there were 20 awards (38.5\%) where investors won and received a damage award. By contrast, there were 30 awards (57.7\%) where tribunals awarded investors nothing. There were also two awards embodying settlement agreements.

The data indicated both governments and investors were successful. Investors and host states won at relatively equivalent rates; and, if anything, the governments won more often. The data suggested that there may be less cause for concern than some commentators suggest. Using the Priest-Klein model, which predicts plaintiffs will win fifty percent of cases, ${ }^{6}$ the close to 50/50 percent win rates suggests the system was functioning effectively. However, this model may not be appropriately applied to investment treaty conflict. Additional thought should be given to this point to determine whether the current win/loss rates reflect successes or shortfalls in the dispute resolution process.

\section{Investors Recover Large Amounts?}

Commentators make claims about the amounts in controversy and investors' ultimate recoveries. For damages claimed, there have been discussions about the lack of reliable information. For damages awarded, there have been references to large awards-such as the US\$133.2 million award in CMS v. Argentina and the US\$269.8 million award in CMEv. Czech Republic - as if they are typical awards; in fact, those were the two largest awards in the population. There are also references to the US\$824 million award in CSOB v. Slovak Republic; and although the case initially included a treaty claim, the final award was not based on a treaty claim.?

Given this background, the data told an interesting story. Out of the 82 cases, 44 quantified an investor's claimed damages, and the average amount claimed was approximately US $\$ 343.4$ million. However, there was a difference between the average amounts claimed and awarded. In the 52 awards finally resolving treaty claims, the average amount tribunals awarded was approximately US $\$ 10.4$ million. The difference between the average amounts claimed and awarded was approximately US $\$ 333$ million. If the outlier Generation Ukraine v. Ukraine is removed, the difference was statistically significant.

As averages are a blunt instrument for assessing these matters, it is helpful to look at the data in other ways. Out of the 52 cases where tribunals finally resolved treaty claims, there were 31 instances in which tribunals awarded investors nothing. There were only four cases in which tribunals awarded investors more than US\$10 million. There were another four cases where tribunals awarded investors between US\$5-10 million and 13 cases where

\footnotetext{
${ }^{5}$ Refer to the North Carolina Law Review article for a full discussion of the comments and attributions made in connection with the claims discussed in these remarks.

${ }^{6}$ George L. Priest \& Benjamin Klein, The Selection of Disputes for Litigation, 13 J. LEGaL STUD. 1 (1984).

${ }^{7}$ See supra note 2.
} 
tribunals awarded investors between US\$5 million and US\$1. This suggests that the majority of investors received nothing and those who did win received US\$10 million or less.

Overall, governments did not fare poorly: liability was less than originally anticipated, and there were few cases with awards over US\$10 million. Likewise, investors recovered in nearly half of the cases, but the four awards over US\$10 million were in the order of US\$17 million, US\$71 million, US\$133 million and US\$270 million. The discrepancy between amounts claimed and received was noteworthy. It suggests that there may be incentives built into the system that create distortion and would benefit from re-consideration to promote institutional integrity.

\section{Who Are the Arbitrators?}

Investment treaty arbitrators make decisions of public significance. Given this role, there have been concerns about the backgrounds of these decision makers. More specifically, some have expressed concerns that arbitrators are a "pale, male and stale," " "mafia or a club",9 while others suggest these claims may "lack a solid evidentiary basis." 10 Understanding the demographics of the arbitrators might provide insights useful insights to address concerns related to institutional legitimacy.

The data provided insights into the demographics of investment treaty arbitrators. Out of 102 awards, 100 awards involved three-member tribunals. In the 102 awards, there were 145 different arbitrators. Although there were repeat appointments, this suggests some breadth in the arbitrator population.

The data were less rosy on issues of nationality and gender. In terms of nationality, the 145 arbitrators were from 40 different countries. Of those arbitrators 109 - or $75 \%$-were from OECD countries. Arbitrators from certain countries were overrepresented. There were multiple arbitrators from Australia and Uruguay; but these countries had neither investors bringing claims nor respondent governments. Other countries were underrepresented. Investors from Luxembourg brought two cases and Pakistan was a respondent in three cases; nevertheless, there were no arbitrators from either country. In terms of gender, there were only 5 women (3\%) in the population of 145 arbitrators. The five women appeared in only 9 cases. There were also no awards with multiple women on a tribunal; by contrast there were 73 cases with all male tribunals. Given these results, it may be useful to consider the utility of broadening the demographics of arbitrators to represent the parties involved and people affected by the disputes.

\section{Preliminary Synthesis}

Investment treaty arbitration is still a relatively new phenomenon and these data only scratch the surface of information about resolving investment treaty conflict. Given this limitation, when considering the broad quantitative data available from public awards, as a general proposition, investment treaty arbitration appears to be functioning relatively well. Disputes arose in only 49 of 1,700 treaties in force. The investor and state win rates were reasonably equivalent. Investors could and did recover, but without exposing governments

\footnotetext{
${ }^{8}$ Michael D. Goldhaber, Madame La Présidente: A Woman Who Sits as President of a Major Arbitral Tribunal Is a Rare Creature. Why?, AM. LAw: Focus EUROPE, Summer 2004, at <http://www.americanlawyer.com/focuseurope/ arbitration04.html>.

${ }^{9}$ Yves Dezalay \& Bryan G. Garth, Dealing in Virtue 10 (1996).

${ }^{10}$ Jan Paulsson, Ethics, Elitims, Eligibility, 14 J. INT'L ARB. 13, 19 (1997).
} 
to massive liability. There was also breadth in the arbitrator pool. Nevertheless, the data suggested that there is room for improvement in the dispute resolution process.

Empirical legal studies can and should inform the evaluation and management of investment treaties and related conflict. More empirical research, done in a scientifically valid and reliable manner, is needed to provide accurate information that stakeholders might usefully consider. Governments might usefully use such information in treaty negotiation, treaty revision and decisions to intervene in cases to which it is not a party. Parties, lawyers, and arbitrators might use the information to use the system more efficiently, provide better advice, make more informed determinations, and better understand the cost and benefits of various dispute resolution strategies. Non-parties also have the ability to make more informed critiques of and interventions in the process.

Overall, should we be willing to utilize it, empirical work can create international law institutions and develop international law theories that are grounded in an empirical reality. This in turn can promote accountability and responsiveness to stakeholders. While the use of such empirical data and their analytical inferences is ultimately a matter of choice and political will, the creation and use of these data has the capacity to promote the legitimacy of an international law process that impacts the daily lives of litigants, governments, and taxpayers alike.

\section{The Evolving International Standard and Sovereignty}

\section{By W. Michael Reisman ${ }^{*}$}

In its modern sense, sovereignty is simply the demand of each territorial community, however small and weak, and however governed, to be permitted to govern itself without interference by larger or more powerful states and, at least in 1945, without interference by any agency of the organized international community. ${ }^{1}$ But the ink was scarcely dry on the UN Charter before the notion of a sovereign domain reservé came under assault from more and more international programs. Each has contributed to expanding the content of the omnibus term, "international minimum standard" into an ambitious and comprehensive governance code of legal and administrative requirements.

As in much international law, implementation has proven episodic and opportunistic. In the macro-economic sphere, international financial institutions used "conditionality" to compel changes in the internal arrangements of states, so-called "structural adjustments," before financial benefits would be extended. The European Union has relied on forms of conditionality with respect to compliance with international human rights prescriptions as a condition for extending recognition or allowing membership in the European system.

Of late, international investment law and its instruments and instrumentalities have come to play a more particularized and assertive role in expanding and applying the international standard. Bilateral investment treaties, or BITs (of which there are some 2,500), seek to establish an orderly framework for investment by creating, in the language of a typical United Kingdom BIT, "favorable conditions for greater investment by nationals and companies of one state in the territory of the other state." The term "favorable conditions" has become code for appropriate internal legal, administrative and regulatory arrangements-all conducted through "transparent" procedures designed to ensure that the arrangements are applied as

\footnotetext{
* Myres S. McDougal Professor of International Law, Yale Law School.

${ }^{1}$ United Nations Charter, Art. 2(7).
} 